\title{
feffings Mertke.
}

Seđâter $\mathfrak{B a n b}$

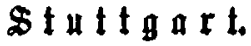

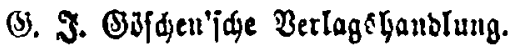

1874. 
A. \$ojbudberdetl 3u Buttenberg (Garl Grininger) in Stuttgart. 